\title{
UPAYA MENINGKATKAN HASIL BELAJAR BAHASA INDONESIA MENGGUNAKAN METODE DEMONSTRASI BERBANTUAN MEDIA WAYANG PADA PESERTA DIDIK KELAS V/A DI SDN-2 BUKIT TUNGGAL PALANGKA RAYA TAHUN PELAJARAN 2017/2018
}

\section{Oleh : NOVIANI KURNIAWATI*Arif Supriyadi, M.Pd}

\begin{abstract}
ABSTRAK
Penelitian ini bertujuan untuk mengetahui: (1) Peningkatan aktivitas belajar Bahasa Indonesia peserta didik kelas $\mathrm{V}$ A SDN-2 Bukit Tunggal Palangka Raya dengan menggunakan metode demonstrasi berbantuan media wayang (2) Peningkatan hasil belajar Bahasa Indonesia peserta didik kelas V A SDN-2 Bukit Tunggal Palangka Raya setelah menggunakan metode demonstrasi berbantuan media wayang. Subjek penelitian ini adalah peserta didik kelas V A SDN-2 Bukit Tunggal yang berjumlah 20 orang.

Jenis penelitian ini adalah Penelitian Tindakan Kelas (PTK). Teknik pengumpulan data yang digunakan yaitu observasi dan tes. Analisis data yang digunakan yaitu analisis kualitatif dan kuantitatif.

Hasil penelitian ini menunjukkan bahwa: (1) Ada peningkatan aktivitas belajar Bahasa Indonesia dengan menggunakan metode demonstrasi berbantuan media wayang pada peserta didik kelas V A SDN-2 Bukit Tunggal Palangka Raya menjadikan peserta didik menjadi baik. Pada siklus I diperoleh skor 2,3 dengan kategori cukup baik, meningkat pada siklus II menjadi 3,33 dengan kategori baik. (2) Ada peningkatan hasil belajar Bahasa Indonesia peserta didik kelas $\mathrm{V}$ A di SDN-2 Bukit Tunggal Palangka Raya dengan menggunakan metode demonstrasi berbantuan media wayang, hal ini dapat dilihat dari tes awal diperoleh nilai rata-rata 55 dengan ketuntasan dengan klasikal 40\%, siklus I diperoleh nilai rata-rata 69 dengan ketuntasan klasikal 55\%, dan pada siklus II diperoleh nilai rata-rata 83 dengan ketuntasan klasikal 100\%.
\end{abstract}

\section{Kata Kunci : Hasil Belajar, Bahasa Indonesia, Metode Demonstrasi Berbantuan Media Wayang.}

\section{PENDAHULUAN}

Pendidikan yang berkualitas perlu seorang guru yang profesional dalam lingkungan sekolah maupun masyarakat. Sebagai seorang guru, tidak hanya memiliki peran untuk menyampaikan materi pembelajaran tapi guru juga harus punya keahlian khusus dalam menciptakan suasana belajar yang menyenangkan. Hal ini dapat dicapai dengan melalui upaya mencerdaskan kehidupan bangsa yang merupakan salah satu cita-cita bangsa Indonesia.

Upaya mewujudkan rita-cita
bangsa Indonesia, raka
pembangunan pendidikan diarahkan
untuk lebih mengembangkan
seluruh potensi peserta didik
semaksimal mungkin.
pendidikan di Indonesia, kususnya
bahasa Indonesia sebagai bahasa
Nasional memiliki peran yang
sangat penting. Pembelajaran
Bahasa Indonesia diharapkan dapat
meningkatkan kemampuan peserta


didik dalam berkomunikasi dengan baik. Keterampilan berbahasa menurut Tarigan (2008) mencakup empat aspek yaitu :

(1) keterampilan menyimak (listening skills); (2) keterampilan berbicara (speaking skills); (3) keterampilan membaca (reading skills); (4) keterampilan menulis (writting skills), dan keempat keterampilan tersebut saling berhubungan satu sama lain.

Tugas seorang pendidik dalam hal ini sangat di perlukan untuk dapat mengembangkan sejak dini potensi peserta didik baik dalam kemampuan kognitif, afektif maupun psikomotor dalam pelajaran Bahasa Indonesia. Tercapainya tujuan pembelajaran tersebut, seorang guru diharapkan dapat menciptakan kondisi dan suasana pembelajaran yang memungkinkan peserta didik aktif menemukan dan mengembangkan pengetahuannya. Serta, peserta didik dapat memahami konsep dan teori dari bahan-bahan pelajaran melalui suatu proses belajar dan dapat dikembangkan lebih lanjut.

Salah satu kemampuan dasar yang harus dimiliki oleh guru adalah merencanakan dan melaksanakan proses belajar mengajar. Kemampuan ini dapat membekali guru dalam melaksanakan tugas dan tanggung jawabnya sebagai pengajar. Belajar dan mengajar terjadi pada saat berlangsungnya interaksi antara guru dengan peserta didik untuk mencapai tujuan pengajaran.

Mengingat pentingnya Bahasa Indonesia dalam kehidupan seharihari, maka materi pembelajaran Bahasa Indonesia harus dikuasai dengan baik. Hal ini mempersiapkan siswa agar sanggup menghadapi perubahan menggunakan Bahasa Indonesia dalam kehidupan seharihari dan dalam mempelajari berbagai ilmu pengetahuan.

Pembinaan dan pengembangan pendidikan diawali dibangku Sekolah Dasar (SD), dimana peserta didik dibina untuk mengembangkan suatau kemampuan, keahlian dan keterampilan yang dimilikinya, untuk menguasai suatu konsep dari mata pelajaran yang ditekuninya di sekolah khususnya pada pelajaran Bahasa Indonesia.

Salah satu upaya untuk meningkatkan hasil belajar peserta didik melalui penggunaan media atau alat peraga yang dapat dibantu dengan model atau metode pembelajaran dalam proses pembelajaran. Konsep pembelajaran yang dibuat diharapkan membuat peserta didik mudah memahami konsep pembelajaran secara nyata berdasarkan fakta yang jelas. Sehingga materi pelajaran yang disampaikan oleh guru lebih mudah dipahami oleh peserta didik.

Menggunakan metode demonstrasi yaitu memperagakan sumber belajar dalam kegiatan sebenarnya dan tidak bersifat abstrak, dengan berbantuan media konkret sesuatu yang nyata dalam bentuk media pembelajaran berbasis wayang merupakan alat bantu visual dalam pembelajaran yang berfungsi dapat merangsang pikiran, perasaan, perhatian dan minat peserta didik merupakan pola pembelajaran yang meningkatkan keterampilan belajar dan keterampilan berkomunikasi 
dalam lingkungan yang menyenangkan.

Berdasarkan hasil observasi yang dilakukan pada hari sabtu, tanggal 6 januari 20018 di kelas V/A SDN-2 Bukit Tunggal Palangka Raya Tahun Pelajaran 2017/2018. Hasil belajar Bahasa Indonesia masih di bawah Kriteria Ketuntasan Minimal (KKM). Terlihat dari nilai rata-rata hasil belajar yang mereka peroleh dalam mata pelajaran bahasa Indonesia, dari jumlah peserta didik sebanyak 20 orang tersebut, terdapat 11 orang yang tuntas yang bila dipresentasekan sejumlah $55 \%$ dan yang belum tuntas berjumlah 9 orang peserta didik atau bila dipresentasekan menjadi $45 \%$. Sementara ketentuan dari sekolah nilai ketuntasan mata pelajaran Bahasa Indonesia di kelas V SDN-2 Bukit Tunggal Palangka Raya yaitu 70.

Masalah hasil belajar di atas didasari oleh beberapa faktor peserta didik kurang memperhatikan guru saat menjelaskan di depan kelas, ketika guru menjelaskan peserta didik hanya mencoret buku atau menggambar, mengobrol dengan teman dan asik bermain. Peserta didik juga belum terlibat aktif dalam mengikuti proses pembelajaran dan ketika guru bertanya, peserta didik tidak ada yang mau mengangkat tangan untuk menjawab pertanyaan tersebut. Model atau metode yang digunakan kurang bervariasi, penggunaan media yang jarang digunakan dalam pembelajaran bahasa Indonesia, dan hasil belajar peserta didik masih di bawah KKM. Perlunya penggunaan metode pembelajaran dengan berbantuan media pembelajaran yang dapat melibatkan peserta didik secara aktif dapat berinteraksi dalam belajar. Berdasarkan fenomena di atas, maka peneliti tertarik melakukan penelitian dengan judul "Upaya Meningkatkan Hasil Belajar Bahasa Indonesia Menggunakan Metode Demonstrasi Berbantuan Media Wayang Pada Peserta Didik Kelas V/A di SDN-2 Bukit Tunggal Palangka Raya Tahun Pelajaran 2017/2018".

Penelitian ini sangat penting karena dengan membiasakan belajar menyenangkan khususnya metode demonstrasi dengan memperagakan atau mempertunjukan suatu proses atau situasi berbantuan media pembelajaran berbasis wayang dalam pembelajaran Bahasa Indonesia dapat memberikan suasana baru dan semangat baru dalam pembelajaran. Sehingga, peserta didik tertarik serta lebih aktif dalam mengikuti pembelajaran.

Menurut Muhibbin Syah dalam

(Aris Shoimin 2014 : 62) menyatakan bahwa : Pendekatan demonstrasi adalah pendekatan mengajar dengan cara memperagakan barang, kejadian, aturan, dan urutan melakukan suatu kegiatan, baik secara langsung maupun melalui penggunaan media pengajaran yang relevan dengan pokok bahasan atau materi yang sedang disajikan. Sedangkan menurut Roestiyah (dalam Miftahul Huda 2013:231) menyatakan bahwa "Demonstrasi adalah suatu strategi mengajar di mana guru memperlihatkan suatu benda asli, benda tiruan, atau suatu proses dari materi yang diajarkan kepada seluruh siswa".

Dari pendapat dua para ahli di atas Dapat ditarik kesimpulan bahwa, dalam metode demonstrasi peserta didik diharapkan dapat memperagakan atau mempertunjukan sesuatu yang dapat digunakan dan diaplikasikan kepada 
peserta didik yang lain, dan dengan begitu peserta didik dapat mengamati dengan sesama prosesnya.

Menurut Miftahul Huda (2013: 232-233) menyebutkan tahap / langkah metode demonstrasi sebagai berikut:

1) Merumuskan dengan jelas jenis kecakapan atau keterampilan yang diperoleh setelah demonstrasi dilakukan.

2) Menentukan peralatan yang digunakan, kemudian diuji coba terlebih dahulu agar pelaksanaan demonstrasi tidak mengalami kegagalan.

3) Menetapkan prosedur yang dilakukan, dan melakukan percobaan sebelum demonstrasi dilakukan.

4) Menentukan durasi pelaksanaan demonstrasi.

5) Memberikan kesempatan kepada siswa untuk memberikan komentar pada saat ataupun sesudah demonstrasi.

6) Meminta siswa untuk mencatat halhal yang dianggap perlu.

7) Menetapkan rencana untuk menilai kemajuan siswa.

Sedangkan menurut pendapat Muhbin syah dalam (Aris shoimin, 2014:62-63) menyebutkan langkahlangkah demonstrasi sebagai berikut

1) Guru menampaikan kompetensi yang ingin dicapai

2) Guru menyajikan gambaran sekilas materi yang akan disampaikan.

3) Menyiapkan bahan dan alat yang akan diperlukan.

4) Menunjuk salah seorang siswa untuk mendemonstrasikan sesuai skenario yang telah disiapkan.

5) Seluruh siswa memperhatikan demonstrasi dan menganalisisnya.

6) Guru dan siswa membuat suatu kesimpulan.

\section{7) Penutup}

Dari dua pendapat para ahli di atas dapat ditarik kesimpulan bahawa, langkah-langkah metode demonstrasi dapat dilakukan oleh pengajar (guru) maupun peserta didik untuk memperagakan atau mempertunjukan alat atau bahan untuk perlengkapan dalam pembelajaran.

Menurut Miftahul Huda (2013:233) menjelaskan kelebihan metode demonstrasi sebagai

berikut :

1) Membuat pengajaran menjadi lebih jelas dan lebih konkret.

2) Memusatkan perhatian siswa.

3) Lebih mengarahkan proses belajar siswa pada materi yang sedang dipelajari.

4) Lebih melekatkan pengalaman dan kesan sebagai hasil pembelajaran dalam diri siswa.

5) Membuat siswa lebih mudah memahami apa yang dipelajari

6) membuat proses pengajaran lebih menarik.

7) Merangsang siswa untuk aktif mengamati dan menyesuaikan antara teori dan kenyataan.

8) Membantu siswa memahami dengan jelas jalannya suatu proses atau kerja suatu benda.

9) Memudahkan berbagai jenis penjelasan.

10) Memperbaiki kesalahan-kesalahan yang terjadi dari hasil ceramah melalui pengamatan dan contoh konkret dengan menghadirkan objek.

Adapun Kelebihan dari metode demonstrasi menurut Djamarah dalam (Aris Shoimin, 2014:63) sebagai berikut :

1) Membantu anak didik memahami dengan jelas jalannya suatu proses atau kerja suatu benda. 
2) Memudahkan berbagai jenis penjelasan.

3) Kesalahan-kesalahan yang terjadi dari hasil ceramah dapat diperbaiki melalui pengamatan dan contoh konkret dengan menghadirkan objek sebenarnya

Menurut Miftahul Huda (2013:233) menjelaskan kekurangan metode demonstrasi sebagai berikut :

1) Mengharuskan keterampilan guru secara khusus.

2) Tidak tersedianya fasilitasfasilitas pendukung, seperti peralatan, tempat dan biaya yang memadai di setiap kelas.

3) Memerlukan kesiapan dan perencanaan yang matang di samping waktu yang cukup panjang.

4) Kesulitan siswa terkadang untuk melihat dengan jelas benda yang akan dipertunjukkan.

5) Tidak semua benda dapat didemonstrasikan.

6) Sukar dimengerti bila di demonstrasikan oleh guru yang kurang menguasai materi atau barang yang didemonstrasikan.

7) Tidak semua benda dapat didemonstrasikan.

Adapun Kekurangan dari metode demonstrasi menurut Djamarah dalam (Aris Shoimin, 2014:63) sebagai berikut :

1) Anak didik terkadang sukar melihat dengan jelas benda yang diperuntukkan kepadanya.

2) Tidak semua benda dapat didemonstrasikan.

3) Sukar dimengerti bila didemonstrasikan oleh guru yang kurang menguasai apa yang didemonstrasikan.

Dari pendapat di atas dapat ditarik kesimpulan bahwa Metode demonstrasi tidak lepas dari kelebihan dan kekurangan dalam penggunaannya dan pengaplikasiannya saat di lapangan. Namun, hal itu tidak menjadikan penghalang untuk guru tetap mencoba berlatih dan belajar dari kekurangan tersebut untuik menjadi pendidik yang lebih baik.

Secara konseptual, media wayang memang sangat luas pengertiannya. Menurut Hamidulloh Ibda (2017 : 65) menyatakan bahwa: Wayang adalah seni tradisional Indonesia yang terutama berkembang di Pulau Jawa dan Bali. Ada Versi wayang yang dimainkan oleh orang dengan memakai kostum, yang dikenal sebagai wayang orang, dan ada pula wayang yang berupa sekumpulan boneka yang dimainkan oleh dalang.

Sedangkan menurut Adrian Kresna (2012 : 21) menyatakan bahwa "Wayang sering diartikan sebagai bayangan atau samar-samar yang bergerak sesuai lakon yang dihidupkan oleh seorang dalang".

Berdasarkan uraian di atas, dapat kita tarik kesimpulan bahwa wayang merupakan suatu kebudayaan, kesenian, atau hasil karya manusia. Bisa mengandung makna gambar, boneka, tiruan manusia yang terbuat dari kulit, kardus, seng dan lain-lain.

Adapun kelemahan dan kelebihan media wayang menurut Hamidulloh Ibda $(2017,166)$ sebagai berikut :

Kelebihan Media Wayang.

1. Dapat memberikan kesempatan semaksimal mungkin pada peserta didik untuk mempelajari sesuatu ataupun melaksanakan tugas-tugas dalam situasi.

2. Memberikan kesempatan kepada peserta didik untuk mengalami sendiri situasi yang sesungguhnya dan melatih keterampilan mereka.

3. Peserta didik dapat berkreasi dan berimajinasi dalam penggunaan media ini. 
4. memberikan pengalaman nyata atau konkret kepada peserta didik.

Kelemahan Media Wayang

1. Biaya yang diperlukan untuk mengadakan media ini kadang-kadang tidak sedikit, apalagi ditambah dengan kemungkinan kerusakan dalam penggunaannya.

2. Tidak semua mata pelajaran dapat menggunakan media ini.

3. Guru dituntut untuk bisa menggunakan media ini.

4. Guru juga dituntut untuk dapat mengembangkan keterampilan.

\section{METODE PENELITIAN}

Jenis penelitian yang digunakan peneliti adalah jenis penelitian tindakan kelas (PTK), karena penelitian ini dilakukan untuk memperbaiki atau meningkatkan hasil belajar peserta didik di kelas V/A, khususnya materi memahami cerita tentang suatu peristiwa dan cerita pendek anak yang di sampaikan secara lisan.

Penelitian Tindakan Kelas (PTK) berasal dari bahasa Inggris, yaitu Classroom Action Research (penelitian dengan tindakan). Menurut Wina Sanjaya (2014 : 149) menyatakan bahwa:

PTK (penelitian tindakan kelas) adalah proses pengkajian masalah pembelajaran di dalam kelas melalui refleksi diri dan upaya untuk memecahkannya dengan cara melakukan berbagai tindakan yang terencana dalam situasi nyata serta menganalisis setiap pengaruh dari tindakan tersebut.

Sedangkan menurut Mulyasa (2009 : 11) menyatakan bahwa : Penelitian Tindakan Kelas merupakan suatu upaya untuk mencermati kegiatan belajar sekelompok peserta didik dengan memberikan sebuah tindakan yang sengaja dimunculkan. Tindakan tersebut dilakukan oleh guru bersama-sama dengan peserta didik, atau oleh peserta didik dibawah bimbingan dan arahan guru, dengan maksud untuk memperbaiki dan meningkatkan kualitas pembelajaran.

Berdasarkan beberapa pendapat di atas dapat disimpulkan bahwa Penelitian Tindakan Kelas adalah suatu bentuk penelitian yang dilakukan oleh guru sebagai peneliti dalam mencermati kegiatan belajar sekelompok peserta didik, yang bertujuan untuk meningkatkan kualitas pembelajaran dan peningkatan situasi tempat praktik berlangsung.

Berdasarkan jenis penelitian yang digunakan yaitu penelitian tindakan kelas (PTK), maka peneliti hadir selama penelitian di sekolah berlangsung. Peran peneliti adalah melakukan penelitian dan berkalaborasi dengan guru kelas $\mathrm{V}$ dan dibantu oleh teman sejawat sebagai observer agar penelitian dapat berjalan dengan lancar dan mencapai tujuan pembelajaran yang diharapkan.

Adapun subjek dalam penelitian ini adalah keseluruhan dari peserta didik kelas V di SDN- 2 Bukit Tunggal Palangka Raya sebanyak 20 orang, untuk lebih jelas ada pada tabel berikut :

Kehadiran peneliti mutlak diperlukan karena kehadiran peneliti sangat diperlukan dalam setiap kegiatan ditempat penelitian. Peneliti berperan sebagai perencana, pelaksana tindakan, peneliti bertindak sebagai pengajar atau guru model yang bertugas membuat rancangan pelaksanaan pembelajaran (RPP) sekaligus menyampaikan bahan ajar selama pembelajaran. Di samping itu, penelitian mengumpulkan dan menganalisis data serta sebagai pelapor hasil penelitian. Sebelum melakukan pengamatan, pada observer dilatih terlebih dahulu agar memahami materi pengamatan dan media Visual yang akan 


\begin{tabular}{|l|l|l|l|}
\hline No & Siklus & $\begin{array}{l}\text { Skor } \\
\text { Rata } \\
\text { Rata }\end{array}$ & $\begin{array}{l}\text { Skor } \\
\text { Maksimal }\end{array}$ \\
\hline 1. & $\begin{array}{l}\text { Siklus } \\
\text { II }\end{array}$ & 3,33 & 4 \\
\hline
\end{tabular}

diterapkan beserta materi yang akan di a arkan kepada peserta didik.

Subjek penelitian dalam penelitian ini adalah peserta didik kelas IV SDN 4 Panarung untuk dijadikan sebagai sumber informasi yang dibutuhkan dalam pengumpulan data penelitian peserta didik berjumlah 21 yang terdiri dari 9 laki-laki dan 12 perempuan. Pengumpulan data yang diperoleh pada penelitian ini dilakukan melalui pengamatan (observasi) dan tes hasil belajar. Penelitian ini menggunakan metode Penelitian Tindakan Kelas (PTK). Analisis data merupakan kegiatan yang dilakukan. Data yang telah dikumpulkan sebelumnya diolah menjadi dua jenis yaitu secara kualitatif dan kuantitatif. Data kualitatif diperoleh dari aktivitas terhadap peneliti dan aktivitas.

\section{HASIL PENELITIAN}

Berdasarkan gambar 3 Grafik di atas dapat diketahui bahwa aktivitas peserta didik dari kedua observer yaitu guru kelas Ibu Erihanie, S.Pd dan teman sejawat Niddia jayanti mengalami peningkatan pada setiap siklusnya yaitu pada siklus I skor rata-rata yang diperoleh peserta didik adalah 2,3 dengan kriteria cukup, sedangkan pada siklus II mengalami peningkatan yaitu skor ratarata yang diperoleh peserta didik adalah 3,33 dengan kriteria baik. Pencapaian ini telah memenuhi syarat kriteria ketuntasan aktivitas peserta didik berdasarkan indikator ketercapaian baik secara individu maupun secara klasikal.

Tabel 20

\section{Hasil Aktivitas Peserta Didik Pada Pembelajaran Siklus II}

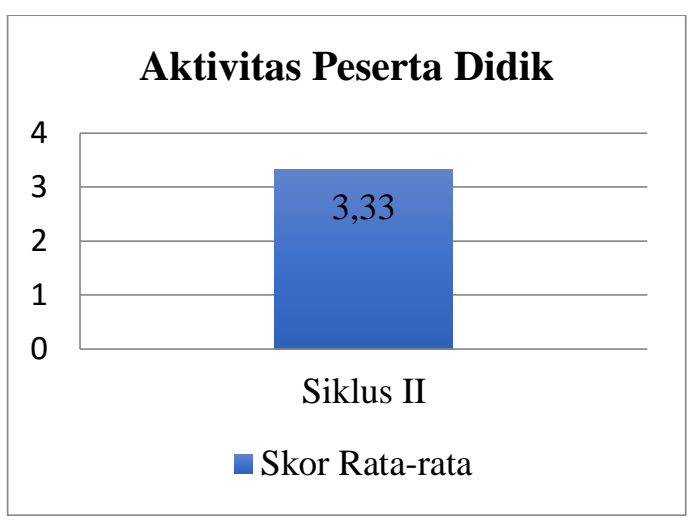

Gambar 3.

\section{Grafik Persentase Aktivitas Peserta}

Terlihat dalam proses pembelajaran, dimana pada siklus I terlihat peserta didik belum terlibat aktif dalam melakukan tanya jawab,mencatat hal-hal yang dianggap penting, dan belum antusias ketika guru menyuruh mejawab pertanyaan. Sedangkan di siklus II peserta didik terlibat aktif dalam melakukan tanya jawab, peserta didik terlihat mencatat hal-hal penting dari penjelasan materi unsur-unsur intrinsik dalam cerita,peserta didik lebih aktif ketika guru menyuruh menjawab pertanyaan dari guru, dan peserta didik tepat waktu dalam menyelesaikan tugas pada akhir pembelajaran. Hal ini menunjukan bahwa dengan menggunakan metode demonstrasi berbantuan media wayang tepat digunakan meningkatkan aktivitas peserta didik dalam pembelajaran Bahasa Indonesia.

Hasil belajar peserta didik setelah menggunakan metode demonstrasi berbantuan media wayang mengalami peningkatan. Hasil belajar peserta didik setelah menggunakan metode demonstrasi berbantuan media wayang mengalami peningkatan, hal ini dapat dilihat dari grafik sebagai berikut: 
Tabel 21

\section{Hasil Belajar Peserta Didik}

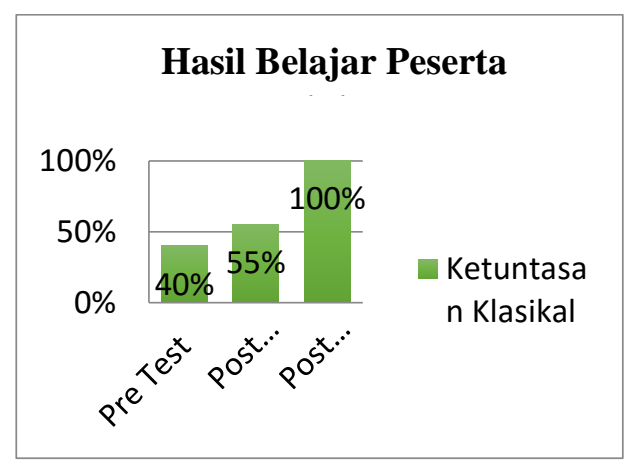

Berdasarkan tabel 21 dan gambar 4 hasil belajar peserta didik di atas dapat dilihat bahwa pada data awal nilai ratarata peserta didik hanya memperoleh nilai 55, nilai ini masih di bawah dari kriteria ketuntasan yang ditentukan yaitu 70 .

Hasil ketuntasan peserta didik pun hanya memperoleh $40 \%$, nilai ini sangat jauh dari nilai kriteria ketuntasan klasikal yang ditentukan yaitu $85 \%$. Kemudian pada siklus I nilai rata-rata peserta didik meningkat menjadi 69 dengan hasil ketuntasan klasikal belajar peserta didik $55 \%$, nilai ini juga belum mencapai kriteria ketuntasan klasikal yang ditentukan. Sehingga harus mengoptimalkan lagi proses pembelajaran pada siklus II yang mana pada akhirnya memperoleh nilai rata-rata 83 dengan hasil ketuntasan klasikal belajar peserta didik $100 \%$. Hal tersebut telah mencapai indikator keberhasilan penelitian yang telah ditetapkan yaitu hasil belajar peserta didik mencapai $\mathrm{KKM} \geq 70$ dengan ketuntasan klasikal $85 \%$.

Data pre test di atas menunjukan tingkat kemampuan peserta didik sebelum penelitian tindakan kelas dilakukan. Dari 20 orang peserta didik ada 1 peserta didik yang memperoleh skor $71-80$, dari 20 orang peserta didik ada 7 peserta didik yang memperoleh skor 61-70, dari 20 orang peserta didik

\begin{tabular}{|c|c|c|}
\hline & Data & $\begin{array}{l}\text { Ketuntasan } \\
\text { Klasikal }\end{array}$ \\
\hline 1 & Pre Test & $40 \%$ \\
\hline 2 & $\begin{array}{ll}\text { Post } & \text { Test } \\
\text { Siklus I } & \end{array}$ & $55 \%$ \\
\hline 3 & $\begin{array}{lr}\text { Post } & \text { Test } \\
\text { Siklus II } & \end{array}$ & $100 \%$ \\
\hline
\end{tabular}

ada 7 peserta didik yang memperoleh skor 41-60, dari 20 orang peserta didik ada 5 peserta didik yang memperoleh skor 0-40. Hasil belajar pada siklus I cukup mencapai indikator penelitian yaitu dengan nilai rata-rata 69 ketuntasan secara klasikal $55 \%$ termasuk dalam kriteria cukup tercapai. Sehingga hasil post test siklus I belum memenuhi syarat ketuntasan belajar secara klasikal dan sebagaian besar peserta didik belum mencapai ketuntasan.

Data hasil post test pada tabel di atas menunjukan tingkat kamampuan peserta didik pada saat penelitian tindakan kelas siklus I yang secara rinci diuraikan sebagai berikut. Dari 20 orang peserta didik ada 1 peserta didik yang memperoleh skor $81-100$, dari 20 orang peserta didik ada 7 peserta didik yang memperoleh skor $71-80$, dari 20 orang peserta didik ada 3 peserta didik yang memperoleh skor $61-70$, dari 20 orang peserta didik 9 peserta didik yang memperoleh skor 41-60, dan dari 20 orang peserta didik tidak ada peserta didik yang memperoleh skor 0-40.

Hasil belajar pada siklus II hasil pos tes menunjukan bahwa dari 20 orang peserta didik telah memperoleh nilai KKM dan tuntas secara keseluruhan yaitu berdasarkan hasil refleksi pada siklus II dengan nilai rata-rata 83 ketuntasan 
secara klasikal $100 \%$ termasuk dalam kriteria sangat tercapai. Sehingga hasil post test siklus II sudah memenuhi syarat ketuntasan belajar secara klasikal dan sebagaian besar peserta didik sudah mencapai ketuntasan.

Data hasil post test pada tabel di atas menunjukan tingkat kamampuan peserta didik pada saat penelitian tindakan kelas siklus II yang secara rinci diuraikan sebagai berikut. Dari 20 orang peserta didik ada 8 peserta didik yang mem peroleh skor $81-100$, dari 20 orang peserta didik ada 12 peserta didik yang memperoleh skor 61-80, dari 20 orang peserta didik tidak ada peserta didik yang memperoleh skor 0-60. Yang artinya sudah sangat mencapai indikator ketercapaian yang telah ditetapkan yaitu $85 \%$.

\section{KESIMPULAN}

1. Aktivitas belajar peserta didik kelas V/A SDN-2 Bukit Tunggal Palangkaraya tahun pelajaran 2018/2019 dalam keterampilan menyimak cerita tentang suatu peristiwa dan cerita pendek anak yang disampaikan secara lisan, mengidentifikasi (tokoh, tema,latar, dan amanat) dengan menggunakan metode demonstrasi berbantuan media wayang menjadi baik. Siklus I skor rata-rata yang diperoleh peserta didik adalah 2,3 dengan kriteria cukup, kemudian pada siklus II skor rata-rata adalah 3,33 dengan kriteria baik.

2. Ada peningkatan keterampilan keterampilan menyimak cerita tentang suatu peristiwa dan cerita pendek anak yang disampaikan secara lisan, mengidentifikasi (tokoh, tema,latar, dan amanat) pada mata pelajaran Bahasa Indonesia dengan menggunakan metode demonstrasi berbantuan media wayang pada peserta didik kelas V/A SDN-2 Bukit
Tunggal Palangkaraya tahun pelajaran 2018/2019. Hal ini dapat dilihat dari nilai rata-rata peserta didik sebelum melaksanakan penelitian tindakan kelas maupun sesudah melaksanakan penelitian tindakan kelas. Sebelum melaksanakan penelitian tindakan kelas atau dilihat dari nilai tes pra tindakan nilai rata-rata yang diperoleh adalah 55 dan ketuntasan klasikal $40 \%$ dengan katagori kurang tercapai. Nilai rata-rata pada siklus I adalah 69 dan ketuntasan klasikal 55\% dengan katagori cukup tercapai. Maka siklus I dianggap belum berhasil. Nilai rata rata pada siklus II adalah 83 dan ketuntasan klasikal $100 \%$ dengan katagori sangat tercapai. Dari hasil yang diperoleh tersebut ada peningkatan antara hasil pra tindakan sebelum melakukan penelitian tindakan kelas dengan hasil post test pada siklus I dan siklus II.

\section{DAFTAR PUSTAKA}

Tarigan, Henry G. (2008). Membaca Sebagai Suatu Keterampilan Berbahasa. Bandung: Angkasa Bandung.

Wina, Sanjaya. (2014). Penelitian Pendidikan. Jakarta: Kencana Prenada Media Group.

Hamidulloh, Ibda. (2017). Media Pembelajaran Berbasis Wayang. Semarang: CV Pilar Nusantara

Huda, Miftahul. (2013). Model-model Pengajaran dan Pembelajran. Yogyakarta: Pustaka Pejara

Shoimin, Aris. (2014). 68 Model Pembelajaran Inovatif dalam kurikulum 2013. Yogyakarta: AR-RUZZ MEDIA. 